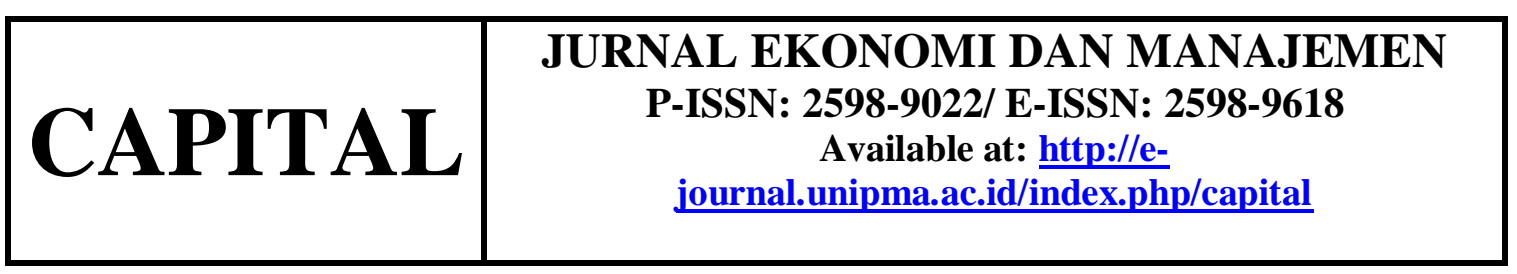

\title{
Pengaruh Person Job-Fit Dan Stres Kerja Terhadap Kepuasan Kerja Karyawan \\ (Studi pada Karyawan Outsource Bank BCA KCU Madiun)
}

\author{
Metik Asmike, Bagus Setiono \\ ${ }^{1}$ Fakultas Ekonomi dan Bisnis, Universitas PGRI Madiun \\ email: smikemetik@gmail.com \\ ${ }^{2}$ Fakultas Ekonomi dan Bisnis, Universitas PGRI Madiun \\ email: bagussetiono@gmail.com
}

\begin{abstract}
PT. Bank Central Asia Tbk, branch office Madiun is a private company engaged in banking. The purpose of this study are to determine the effect of person job-fit and job stress on job satisfaction in outsourced employees of Bank BCA KCU Madiun. This research is a quantitative study with data collection techniques through questionnaires distributed to employees. Sampling of this study using a questionnaire. With a population of 50 outsourced employees. The collected data is then processed using multiple linear regression analysis. The results of the test found that: (1) There is a significant influence between job-fit person on job satisfaction; (2) There is a significant negative effect between job stress on job satisfaction on Outsourced Bank BCA KCU Madiun employees.
\end{abstract}

Keywords: Person Job-Fit, Job Stress and Job Satisfaction

\begin{abstract}
Abstrak
Perusahaan PT. Bank Central Asia Tbk, KCU Madiun merupakan perusahaan swasta yang bergerak di bidang perbankan, Tujuan dari penelitian ini yaitu: untuk mengetahui pengaruh person job-fit dan stress kerja terhadap kepuasan kerja pada karyawan outsource Bank BCA KCU Madiun. Penelitian ini merupakan penelitian kuantitatif dengan teknik pengambilan data melalui kuesioner yang disebar pada karyawan.Pengambilan sampel penelitian ini menggunakan kuisioner. Dengan populasi sebanyak 50 karyawan outsource. Data yang terkumpul kemudian diolah dengan menggunakan analisis regresi linier berganda.Hasil dari pengujian ditemukan bahwa: (1) Terdapat pengaruh yang signifikan antara person job-fit terhadap kepuasan kerja (2) Terdapat pengaruh negativ yang signifikan antara stres kerja terhadap kepuasan kerja pada Karyawan Outsource Bank BCA KCU Madiun.
\end{abstract}

Kata Kunci: Person Job-Fit, Stres Kerja dan Kepuasan Kerja.

\section{A. PENDAHULUAN}

Sumber daya manusia mempunyai peranan penting dalam suatu organisasi perusahaan, semua pihak telah menyadari betapa pentingnya manajemen sumber daya dan tampaknya telah menjadi kebutuhan pokok bagi organisasi baik dalam organisasi besar maupun organisasi kecil. Bahkan semua perusahaan selalu membenahi diri dalam organisasi agar bisa mencapai tujuan seperti yang telah ditargetkan oleh perusahaan. 
Menghadapi persaingan zaman saat ini, dunia kerja sangatlah membutuhkan orang yang mampu berfikir maju, inovatif dan mampu berkarya dengan semangat yang tinggi di dalam organisasi.Sumber daya manusia memiliki person yang sangat penting tetapi harus diimbangi dengan kemampuan dalam pengelolaan organisasi baik dari segi kesiapan maupun pengalaman untuk mencapai tujuan kelangsungan hidup organisasi, maka sumber daya manusia harus meningkatkan kinerjanya.Menurut Handoko (2011, hlm 193) salah satu kepuasan kerja adalah keadaan emosional yang menyenangkan atau tidak menyenangkan bagi karyawan dalam menilai pekerjaan mereka.

Handoko (2011, hlm 193) mengatakan kepuasan mencerminkan perasaan seseorang terhadap pekerjaannya dimana keadaan emosional yang menyenangkan dan tidak menyenangkan sangat mempengaruhi hasil kepuasan kerja karyawan.Karyawan dapat dipertahankan perusahaan dengan selalu konsisten saat bekerja dan selalu memberikan rasa puas bagi perusahaan. Rasa nyaman dan aman dalam bekerja akan membuat karyawan mudah dalam menyelesaikan pekerjaan baik sebelum menyelesaiakan pekerjaan maupun sesudah menyelesaikan pekerjaan yang di berikan perusahaan serta di dukung rekan kerja yang bisa di ajak untuk diskudi dalam menyelesaikan pekerjaan.

Perlu adanya kesesuaian antara person job-fit dengan pekerjaan, kesesuaian kepribadian pekerjaan (person job-fit) didasarkan dari kesesuaian karyawan dengan pekerjaanya (Robbins dan Judge, 2008:171). Holland dalam penelitiannya menyatakan bahwa ketika kepribadian dan pekerjaan sangat cocok maka akan memunculkan kepuasan dalam diri karyawan meningkat. Seperti contohnya orang yang realistis berada dalam situasi yang realistis lebih sesua dari pada orang yang realistis berada dalam situasi yang konvensional (Robbins dan Judge 2008:171).

Menurut Cable dan Derue (2002) Person-job fit diartikan sebagai karyawan harus mampu menyesuaikan pekerjaan yang ada dengan kemampuan yang dimiliki, dimana karyawan selalu belajar penyesuaian dan selalu memberikan kepuasan walaupun tidak ada persamaan antara pekerjaan dengan kemampuan yang dimiliki. Fenomena dalam penelitian ini menunjukkan bahwa BCA merupakan bank terbesar di tanah air, ini sudah dipercaya oleh seluruh nasabah karena selalu memberikan inovasi serta kecanggihan fasilitas yang dirasa sangat memudahkan nasabah untuk bertransaksi meliputi mesin setor tarik, BCA Mobile, teller star (setor tarik) dan lain-lain. 
Kesuksesan BCA tidak luput dari peran karyawan reguler (tetap maupun karyawan outsource) yang selalu memberikan layanan kepada nasabah agar merasa nyaman, cepat dan aman. Karena tidak ada kesesuaian antara kerpibadian dengan pekerjaan (person job fit) mayoritas tenaga outsource yang meliputi divisi security, driver, dan building manajemen yang membawahi (Teknisi,Office Boy, Cleaning service). Akhirnya orientasi karyawan yang bekerja di bagian outsource merasa tidak adanya jaminan keamanan pekerjaan yang tetap.

Penelitian yang dilakukan oleh Karissa Sekar Ayu dan Th. Agung M. Harsiwi (2016) dengan judul Pengaruh Person-Organization Fit Terhadap Kepuasan Kerja Dengan Dukungan Atasan Langsung Sebagai Pemediasi Pada UD. Hasil penelitian menunjukkan Person-Organization Fit secara positif dan signifikan mempengaruhi kepuasan kerja, sehingga Person-Organization Fit yang tinggi maka kepuasan kerja karyawan juga tinggi. Person-Organization Fit secara positif dan signifikan mempengaruhi dukungan atasan langsung, sehingga Person-Organization Fit yang tinggi maka akan meningkatkan dukungan atasan langsung yang dirasakan karyawan.

Dukungan atasan langsung secara positif dan signifikan mempengaruhi kepuasan kerja, sehingga semakin tinggi dukungan atasan langsung yang dirasakan karyawan maka akan semakin tinggi juga kepuasan kerja karyawan. Dukungan atasan langsung sebagai mediator pengaruh Person-Organization Fit positif dan signifikan terhadap kepuasan kerja terbukti mampu memediasi hubungan Person-Organization Fit dan kepuasan kerja sepenuhnya.

Lain yang dilakukan oleh Niken Widyastuti (2016) dengan judul Pengaruh Stres Kerja Dan Beban Kerja Terhadap Kinerja SKPD Kabupaten Sintang Kalimantan Barat menunjukkan bahwa stres kerja $\left(\mathrm{X}_{1}\right)$ berpengaruh terhadap kinerja pegawai/SKPD (Y).Variabel beban kerja $\left(\mathrm{X}_{2}\right)$ berpengaruh terhadap kinerja pegawai (Y).Variabel stres kerja dan beban kerja secara simultan berpengaruh terhadap kinerja SKPD Kabupaten Sintang Kalimantan Barat.

Demikian pula penelitian yang dilakukan oleh Ollani Vabiola Bangun, I Wayan Gede Supartha dan Made Subudi (2017) tentang Pengaruh Person-Job Fit Dan PersonOrganization Fit Terhadap Komitmen Organisasional Dan Organizational Citizenship Behavior (OCB). Hasil penelitian ini menunjukan bahwa person-job fit berpengaruh positif dan signifikan terhadap komitmen organisasional dan $\mathrm{OCB}$, person-organization 
fit berpengaruh positif dan signifikan terhadap komitmen organisasional tetapi tidak berpengaruh signifikan terhadap OCB. Selanjutnya, komitmen organisasional terbukti memiliki pengaruh yang positif dan signifikan terhadap OCB.Implikasi praktis dari penelitian ini adalah membantu organisasi untuk merekrut dan memiliki standar evaluasi yang baik sehingga memiliki sumber daya manusia yang berkualitas.

Namun hal ini berbeda dengan penelitian yang dilakukan oleh Muhammad Alfani \& Muhammad Hadini (2017) Pengaruh Person Job Fit dan Budaya Kerja Terhadap Organizational Citizenship Behavior Karyawan Kantor Rektorat Universitas Islam Kalimantan (Uniska). Berdasarkan hasil analisis dan pembahasan, maka dapat dinyatakan bahwa person job fit tidak signifikan dan tidak berpengaruh terhadap Organizational Citizenship Behavior Atau kewargaan prilaku karyawan Kantor Rektorat Universitas Islam Kalimantan (Uniska).

Sedangkan yang dilakukan oleh Yasinta Indah Nastiti (2016) dalam penelitian yang membahas tentang Pengaruh Stres Kerja Terhadap Kinerja Karyawan Pada Perusahaan Batik Brotoseno Sragen menunjukkan bahwa hasil variabel stres kerja lingkungan memiliki pengaruh signifikan negatif terhadap kinerja karyawan. Dari uraian di atas maka penelitian ini membahas tentang Pengaruh Person Job-Fit dan Stres Kerja Terhadap Kepuasan Kerja Karyawan.

\section{B. TINJAUAN PUSTAKA}

\section{Pengertian Person-Job Fit}

Rosari (2009:258) menyebutkan bahwa teori person-job fit didasari dari kepribadian karyawan dengan pekerjaannya. Ketika kepribadian karyawan dengan pekerjaan sejalan maka kepuasan dari karyawan akan meningkat dengan sendirinya. Artinya seseorang akan lebih memahami makna dari pekerjaannya sehingga dapat kesempatan untuk mengembangkan dirinya di dalam dunia kerja. Salah satu teori tentang tipe kepribadian yang perlu diperhatikan adalah teori person-job fit.

Sesuai dengan teori ini tipe-tipe kepribadian seseorang digolongkan sesuai dengan lingkungan kerja yang diminati karyawan dalam perusahaan. Dengan memperhatikan tipe kepribadian dalam teori person-job fit tersebut diharapkan pemimpin perusahaan dapat mengetahui tipe kepribadian dari para karyawan dan

pemimpin dapat mempromosikan karyawan di bagian yang cocok dengan 
kepribadiannya (Abdillah dan Satiningsih, 2013). Dalam hal ini karyawan merasakan rasa puas dan cinta terhadap pekerjaan yang ia miliki dan ia kerjakan sekarang tanpa merasa terbebani secara berlebihan atas pekerjaan yang ia kerjakan kesehariannya.

Person-job fit diartikan sebagai Sekiguchi (2004) mendefenisikan person-job fit sebagai kesesuaian antara kemampuan seseorang dengan tuntutan pekerjaan atau keinginan seseorang dan atribut pekerjaan. (Sekiguchi dalam Ollani Vabiola dkk,2016). Jadi menurut teori person-job-fit, adanya kesesuaian antara karakteristik tugas pekerjaan dengan kebutuhan individu untuk melaksanakan tugas tersebut, akan memperkuat keikatan pegawai pada saat bekerja, yaitu pegawai akan lebih komitmen terhadap pekerjaan.

Telah diakui bahwa persyaratan dari pekerjaanlah yang memperlunak hubungan antara karakteristik pribadi yang dimiliki seseorang dengan kinerja pekerjaan. Menurut Holland seperti dikutip oleh Robbins (2010:312) menyatakan bahwa teori kesesuaian individu dengan pekerjaan didasarkan pada gagasan kesesuaian antara karakteristik seorang individu dengan lingkungan kerjanya.Holland menyajikan enam tipe karakteristik individu dan mengemukakan bahwa kepuasan dan kecenderungan untuk meninggalkan suatu pekerjaan bergantung pada suatu lingkungan pekerjaan. 6 tipe karakteristik person-job fi tyaitu:

Tabel 2.1 Tipe Karakteristik Person-Job Fit

\begin{tabular}{|l|l|}
\hline \multicolumn{1}{|c|}{ Tipe } & \multicolumn{1}{|c|}{ Karakteristik } \\
\hline $\begin{array}{l}\text { Realistik : lebih memilih kegiatan fisik } \\
\text { yang memerlukan keterampilan, } \\
\text { kekuatan dan koordinasi. }\end{array}$ & Pemalu, gigih, praktis \\
\hline $\begin{array}{l}\text { Investigasi : Lebih memilih aktivitas } \\
\text { yang cenderung berfikir, mengorganisir. }\end{array}$ & Suka bergaul, ramah, kooperatif \\
\hline $\begin{array}{l}\text { Sosial : lebih memilih kegiatan yang } \\
\text { membantu dan membantu orang lain. }\end{array}$ & $\begin{array}{l}\text { Menyesuaikan diri, efisien, praktikal, } \\
\text { fleksibel }\end{array}$ \\
\hline Konvensional : lebih suka aturan, tertib & $\begin{array}{l}\text { Percaya diri, ambisius, energik, } \\
\text { dominan }\end{array}$ \\
\hline $\begin{array}{l}\text { Enterprising: lebih memilih kegiatan } \\
\text { verbal dimana ada kesempatan untuk } \\
\text { mempengaruhi orang lain dan } \\
\text { memperoleh kekuasaan. }\end{array}$ & $\begin{array}{l}\text { Imajinatif, idealis, emosional, tidak } \\
\text { peraktis }\end{array}$ \\
\hline $\begin{array}{l}\text { Artistic }: \text { lebih tidak sistematis yang } \\
\text { memungkinkan mengungkapkan } \\
\text { kreativitas }\end{array}$ & Pelukis, pemusik, penulis, dekorator \\
\hline
\end{tabular}

Sumber: Robbins (2007:119) 
Dikemukakan oleh Mondy dan Noe (2010:183) yang menjelaskan bahwa kesesuaian karyawan dengan pekerjaan dan organisasi merupakan faktor yang tidak kalah pentingnya dengan persyaratan yang lainnya dalam penerimaan karyawan di suatu organisasi.Sehingga akan diperoleh karyawan yang benar-benar memiliki kompetensi yang diinginkan organisasi, yaitu yang mampu untuk berubah mengikuti perkembangan.

\section{Pengertian Stres Kerja}

Karyawan dapat menanggapi kondisi-kondisi tekanan yang di hadapinya di perusahaan secara positif maupun negatif.Stres dapat dinyatakan positif dan merupakan suatu peluang apabila stres tersebut dapat mempengaruhi mereka untuk meningkatkan usahanya agar memperoleh hasil optimal.

Stres dapat dikatakan negatif apabila stres tersebut menyebabkan hasil yang menurun pada produktifitas karyawan. Robbins (2007:793) mendefinisikan stress adalah kondisi dinamik yang didalamnya individu menghadapi peluang kendala, atau tuntutan yang terkait dengan apa yang sangat diinginkannya dan hasilnya dipersepsikan sebagai tidak pasti tetapi penting.

Stres kerja adalah kondisi ketergantungan yang mempengaruhi emosi, proses berfikir dari seseorang.Orang orang yang mengalami stres menjadi nervous dan merasakan kondisi kronis (Malayu S.P Hasibuan, 2011: 201).Stres kerja merupakan suatu bentuk tanggapan seseorang, baik fisik maupun mental terhadap suatu perubahan di lingkungannya yang dirasakan mengganggu dan mengakibatkan dirinya terancam (Anoraga, 2008:108).

Stres kerja merupakan reaksi-reaksi emosional dan psikologis yang terjadi pada situasi dimana tujuan individu mendapat halangan dan tidak biasa mengatasinya Rivai \& Mulyadi, 2005:308). David dan Newstrom (2007 : 368) memberikan definisi tentang stres kerja yaitu suatu kondisi yang mempengaruhi emosi, proses pikiran, dan kondisi fisik seseorang.

Sedangkan menurut Sopiah (2008:85) stress merupakan suatu respons adoptif terhadap suatu situasi yang dirasakan menantang atau mengancam kesehatan seseorang. Stres kerja adalah perasaan yang menekan atau merasa tertekan yang dialami karyawan dalam menghadapi pekerjaan. Stress kerja ini tampak dari simpton 
antara lain emosi tidak stabil, perasaan tidak tenang, suka menyendiri, sulit tidur, merokok yang berlebihan, tidak bisa rileks, cemas, tegang, gugup, tekanan darah meningkat dan mengalami gangguan pencernaan (Mangkunegara, 2010:28).

Sondang P. Siagian (2014) mengemukakan bahwa stres merupakan situasi menegangkan yang mempengaruhi emosi dan pola pikir seseorang. Jika stres tidak diatasi dengan bijak maka akan berakibat pada ketidakmampuan seseorang berkomunikasi dengan lingkungannya. Artinya karyawan yang mengalami stres akan dihadapkan gejala yang buruk yang dapat mempengaruhi prestasi kerjanya.

Para ahli menegaskan bahwa stres akan muncul diakibatkan dari tekanan yang tidak selaras dari seseorang dan lingkungan. Sehingga sarana dan tuntutan tugas yang tidak sesuai dari kemampuan dan kebutuhan seseorang. Dalam dunia pekerjaan harapan mengalami stres cukup tinggi, ketegangan interaksi dengan atasan, pekerjaan dengan konsentrasi tinggi, beban kerja yang melebihi kemampuan, lingkungan kerja yang tidak mendukung, ketatnya persaingan, dan lain sebagainya.Sehingga stres kerja dapat ditimbulkan dari suatu kondisi penghayatan berupa interaksi antara lingkungan kerja dan individu.

Menurut Sopiah (2008:87) penyebab stress yang berhubungan dengan pekerjaan terbagi atas empat tipe utama, yaitu:

1) Lingkungan Fisik

Beberapa stressor ditemukan dalam lingkungan fisik pekerjaan, seperti terlalu bising, kurang baiknya penerangan ataupun resiko keamanan.

2) Stres karena peran atau tugas

Stressor karena peran/tugas termasuk kondisi di mana para pegawai mengalami kesulitan dalam memahami apa yang menjadi tugasnya, peran yang dia mainkan dirasakan terlalu berat atau memainkan berbagai peran pada tempat mereka bekerja.

3) Penyebab stress antar pribadi (interpersonal stressor)

Stressor ini akan semakin bertambah ketika karyawan dibagi dalam divisi-divisi dalam suatu departemen yang dikompetisikan untuk memenangkan target sebagai divisi terbaik dengan rewrad yang mengiurkan. 
4) Organisasi

Banyak sekali ragam penyebab stress yang bersumber dari organisasi. Pengurangan jumlah pegawai merupakan salah satu penyebab stress yang tidak hanya untuk mereka yang kehilangan pekerjaan, namun juga untuk mereka yang masih tinggal.

\section{Pengertian Kepuasan Kerja}

Setiap orang yang bekerja mengharapkan memperoleh kepuasan dari tempatnya bekerja. Pada dasarnya kepuasan kerja merupakan hal yang bersifat individual karena setiap individu akan memiliki tingkat kepuasan yang berbeda-beda sesuai dengan nilai-nilai yang berlaku dalam diri setiap individu. Semakin banyak aspek dalam pekerjaan yang sesuai dengan keinginan individu, maka semakin tinggi tingkat kepuasan yang dirasakan. Menurut Kreitner dan Kinicki (2010;271) kepuasan kerja adalah "suatu efektifitas atau respons emosional terhadap berbagai aspek pekerjaan. Davis dan Newstrom (2007:105) mendeskripsikan kepuasan kerja adalah seperangkat perasaan pegawai tentang menyenangkan atau tidaknya pekerjaan mereka.

Menurut Robbins $(2003 ; 78)$ kepuasan kerja adalah sikap umum terhadap pekerjaan seseorang yang menunjukkan salah satu aspek pekerjaan dan tidak puas dengan satu atau lebih aspek lainnya. Kepuasan Kerja merupakan sikap (positif) tenaga kerja terhadap pekerjaannya, yang timbul berdasarkan penilaian terhadap situasi kerja.Penilaian tersebut dapat dilakukan terhadap salah satu pekerjaannya, penilaian dilakukan sebagai rasa menghargai dalam mencapai salah satu nilai-nilai penting dalam pekerjaan.Karyawan yang puas lebih menyukai situasi kerjanya daripada tidak menyukainya. Perasaan-perasaan yang berhubungan dengan kepuasan dan ketidak puasan kerja cenderung mencerminkan penaksiran dari tenaga kerja tentang pengalaman-pengalaman kerja pada waktu sekarang dan lampau dari pada harapan-harapan untuk masa depan.

Kepuasan kerja merupakan pernyataan emosional yang positif yang merupakan hasil evaluasi dari pengalaman kerja. (Malthis, dalam Sopiah, 2008:170).Sehingga dapat disimpulkan bahwa terdapat dua unsur penting dalam kepuasan kerja, yaitu nilai-nilai pekerjaan dan kebutuhan-kebutuhan dasar.Nilai-nilai pekerjaan merupakan 
tujuan-tujuan yang ingin dicapai dalam melakukan tugas pekerjaan.Yang ingin dicapai ialah nilai-nilai pekerjaan yang dianggap penting oleh individu. Dikatakan selanjutnya bahwa nilai-nilai pekerjaan harus sesuai atau membantu pemenuhan kebutuhan-kebutuhan dasar.

Dengan demikian dapat disimpulkan bahwa kepuasan kerja merupakan hasil dari tenaga kerja yang berkaitan dengan motivasi kerja.Kepuasan kerja secara keseluruhan bagi seorang individu adalah jumlah dari kepuasan kerja (dari setiap aspek pekerjaan) dikalikan dengan derajat pentingnya aspek pekerjaan bagi individu. Seorang individu akan merasa puas atau tidak puas terhadap pekerjaannya merupakan sesuatu yang bersifat pribadi, yaitu tergantung bagaimana ia mempersepsikan adanya kesesuaian atau pertentangan antara keinginankeinginannya dengan hasil keluarannya (yang didapatnya). Sehingga dapat disimpulkan pengertian kepuasan kerja adalah sikap yang positif dari tenaga kerja meliputi perasaan dan tingkah laku terhadap pekerjaannya melalui penilaian salah satu pekerjaan sebagai rasa menghargai dalam mencapai salah satu nilai-nilai penting pekerjaan.

Ada lima faktor yang dapat mempengaruhi kepuasan kerja menurut Kreitner dan Kinicki $(2001 ; 225)$ yaitu sebagai berikut :

1) Pemenuhan kebutuhan (Need fulfillment)

Kepuasan ditentukan oleh tingkatan karakteristik pekerjaan memberikan kesempatan pada individu untuk memenuhi kebutuhannya.

2) Perbedaan (Discrepancies)

Kepuasan merupakan suatu hasil memenuhi harapan. Pemenuhan harapan mencerminkan perbedaan antara apa yang diharapkan dan apa yang diperoleh individu dari pekerjaannya. Bila harapan lebih besar dari apa yang diterima, orang akan tidak puas. Sebaliknya individu akan puas bila menerima manfaat diatas harapan.

3) Pencapaian nilai (Value attainment)

Kepuasan merupakan hasil dari persepsi pekerjaan memberikan pemenuhan nilai kerja individual yang penting. 
4) Keadilan (Equity)

Kepuasan merupakan fungsi dari seberapa adil individu diperlakukan di tempat kerja.

5) Komponen genetik (Genetic components)

Kepuasan kerja merupakan fungsi sifat pribadi dan faktor genetik. Hal ini menyiratkan perbedaan sifat individu mempunyai arti penting untuk menjelaskan kepuasan kerja disamping karakteristik lingkungan pekerjaan.

\section{Kerangka Berpikir dan Hipotesis}

Penelitian ini melibatkan tiga variabel yang terdiri atas 3 variabel independen dan satu variabel dependen. Variabel independen dalam penelitian ini adalah person-job fitdan stress kerja sedangkan variabel dependen adalah kepuasan kerja dapat dianalogikan dengan gambar sebagai berikut :

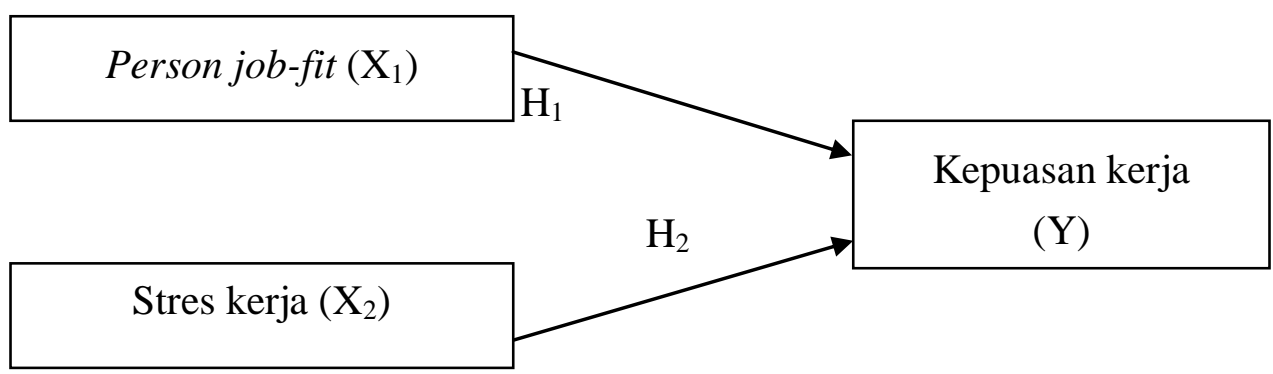

Gambar 2. 1. Kerangka Berpikir

$\mathrm{H}_{1}$ : Diduga Person-Job Fit secara parsial berpengaruh terhadap Kepuasan Kerja pada Karyawan Outsource Bank BCA KCU Madiun.

$\mathrm{H}_{2}$ : Diduga Stres Kerja secara parsial berpengaruh terhadap Kepuasan Kerja pada Karyawan Outsource Bank BCA KCU Madiun.

\section{METODE PENELITIAN}

Populasi adalah keseluruhan subyek penelitian.(Arikunto, 2010:115). Berdasarkan pendapat tersebut, maka populasi dalam penelitian ini adalah Karyawan Outsource pada Bank BCA KCU Madiun sebanyak 50 orang yang terdiri dari Security, Cleanig service, Office boy, Teknisi / Maintenance, Sekertaris Ao, Driver dan Teknisi Mesin 
Edc.Sementara untuk teknik pengumpulan data menggunakan wawancara dan kuesioner dimana didalamnya menggunakan skala likert.

Uji validitas dilakukan untuk mengetahui apakah item-item yang tersaji dalam kuisioner benar-benar mampu mengungkapkan dengan pasti apa yang akan diteliti. Pengujian validitas menggunakan pearson Correlation yaitu dengan cara menghitung korelasi antara skor masing-masing butir dengan total skor.Uji reliabilitas data adalah suatu uji yang dilakukan untuk mengukur suatu kuisioner yang merupakan indikator dari suatu variabel atau kontruk. Dengan kata lain, alat ukur tersebut mempunyai hasil konsisten apabila digunakan berkali-kali pada waktu yang berbeda. Selain itu dilakukan juga uji asumsi klasik yang meliputi: uji autokorelasi, uji multikolinearitas, heteroskedatisitas, dan uji normalitas. Sementara untuk uji hipotesis dilakukan uji t dan uji f.

\section{HASIL DAN PEMBAHASAN}

Uji validitas digunakan untuk mengetahui layak (sahih) dan tidaknya pertanyaan. Kriteria keputusannya adalah dengan membandingkan nilai corrected item - total correlation ( $\mathrm{r}_{\text {hitung }}$ )dengan nilai $\mathrm{r}_{\text {tabel }}$ yaitu $\mathrm{df}=\mathrm{n}-2=(50-2)=48$ diperoleh $\mathrm{r}_{\text {tabel }}=$ 0,2787 . Apabila nilai corrected item - total correlation lebih besar dari $r_{\text {tabel }}(0,2787)$ maka indikator layak (valid) dan sebaliknya.Berdasarkan uji validitas menunjukkan pertanyaan Person-Job Fit $\left(\mathrm{X}_{1}\right)$, dinyatakan valid. Hal ini ditandai dengan nilai corrected item - total correlation $\left(\mathrm{r}_{\text {hitung }}\right)>\mathrm{r}_{\text {tabel }}(0,278)$. uji validitas pertanyaan Stres Kerja $\left(\mathrm{X}_{1}\right)$, dinyatakan valid. Hal ini ditandai dengan nilai corrected item - total correlation $\left(\mathrm{r}_{\text {hitung }}\right)>\mathrm{r}_{\text {tabel }}(0,2787)$. Berdasarkan uji validitas menunjukkan pertanyaan Kepuasan Kerja (Y), dinyatakan valid. Hal ini ditandai dengan nilai corrected item total correlation $\left(\mathrm{r}_{\text {hitung }}\right)>\mathrm{r}_{\text {tabel }}(0,2787)$.

Suatu kuesioner dikatakan reliabel atau handal jika jawaban seseorang terhadap pertanyaan adalah konsisten atau stabil dari waktu ke waktu. Pengukuran reliabilitas dapat dilakukan dengan caraone shit atau pengukuran sekali saja. Pengukuran dilakukan hanya sekali dan kemudian hasilnya dibandingkan dengan pertanyaan lain ataumengukur korelasi antar jawaban pertanyaan. Suatu variabel dikatakan reliabel jika memberikan nilai cronbach alpha> 0,70. Hasil uji menunjukkan bahwa seluruh variabel 
memiliki nilai cronbach alpha diatas 0,70 dengan demikian dinyatakan bahwa instrumen masing-masing variabel adalah reliabel.

Disimpulkan bahwa hasil uji validitas dan reliabilitas pada item-item pernyataan variabel Person-Job Fit, Stres Kerja, dan Kepuasan Kerja bahwa keseluruhan item variabel dinyatakan valid dan reliabel. Sehingga kusioner layak dan sah digunakan sebagai instrumen pengumpulan data pada penelitian ini.Setelah uji validitas dan reliabilitas dilakukan, langkah selanjutnya adalah uji asumsi klasik.Dalam pengujian data diperoleh hasil bahwa data yang digunakan dalam penelitian ini terbebas dari masalah asumsi klasik.

Dari data kuesioner yang telah ditabulasikan dan dilakukan analisis menggunakan regresi berganda dengan bantuan program SPSS versi 24 sebagai berikut:

Tabel 4.1Analisa Regresi Berganda

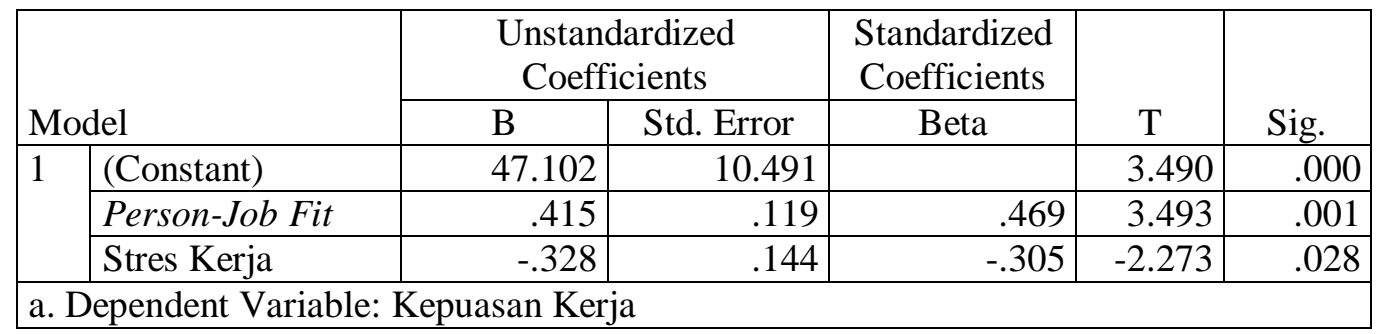

Sumber Data : Hasil Perhitungan SPSS, Lampiran 6

Dari tabel di depan dapat dirumuskan persamaan regresi sebagai berikut: $\mathrm{Y}=47,102$ $+0,415 \mathrm{X}_{1}+\left(-0,328 \mathrm{X}_{2}\right)$. Interpretasi dari persamaan di atas adalah sebagai berikut :

a. $a=47,102$; menunjukkan besarnya Kepuasan Kerjasebelum dipengaruhi Person JobFit $\left(\mathrm{X}_{1}\right)$ dan Stres Kerja $\left(\mathrm{X}_{2}\right)$. Jadi, apabila Person Job-Fit $\left(\mathrm{X}_{1}\right)$ dan Stres Kerja $\left(\mathrm{X}_{2}\right)$ sebesar 0 maka nilai kepuasan kerja akan sebesar 47,102.

b. $b_{1}=0,415$; variabel Person Job-Fit mempunyai pengaruh sebesar 0,415 untuk meningkatkan Kepuasan Kerja. Jadi, apabila Person Job-Fit naik satu satuan akan menaikkan Kepuasan Kerja sebesar 0,415.

c. $b_{2}=-0,328$; variabel Stres Kerja mempunyai pengaruh sebesar -0,328 untuk menurunkan Kepuasan Kerja. Jadi, apabila Stres Kerja naik satu satuan akan menurunkan Kepuasan Kerja sebesar 0,328. 
Berdasarkan hasil analisis regresi linier berganda dapat disimpulkan bahwa variabel Person Job-Fit $\left(\mathrm{X}_{1}\right)$ mempunyai pengaruh yang lebih besar dalam menaikkan Kepuasan Kerja dibandingkan dengan variabel lainnya.

Uji t ini juga disebut dengan uji parsial, pengujian ini bertujuan untuk menguji signifikan hasil dari uji regresi secara parsial. Langkah-langkahnya :

a. $\mathrm{H}_{0}: \mathrm{b}_{1}=0$ artinya, variabel Person Jo-Fit secara parsial tidak berpengaruh terhadap variabel Kepuasan Kerja.

$\mathrm{H}_{\mathrm{i}}: \mathrm{b}_{1}>0$ artinya, variabel Person Jo-Fit secara parsial berpengaruh terhadap variabel Kepuasan Kerja.

$\mathrm{H}_{0}: \mathrm{b}_{2}=0 \quad$ artinya, variabel Stres Kerja secara parsial tidak berpengaruh terhadap variabel Kepuasan Kerja.

$\mathrm{H}_{\mathrm{i}}: \mathrm{b}_{2}>0 \quad$ artinya, variabel Stres Kerja secara parsial berpengaruh terhadap variabel Kepuasan Kerja.

b. $\quad \alpha=0,05$ dengan df $(\mathrm{n}-\mathrm{k}-1)=50-2-1=47 ; \mathrm{t}_{\text {tabel }}=2,011$

c. Kriteria pengujian:

1) Bila $\mathrm{t}$ hitung $>\mathrm{t}$ tabel, maka $\mathrm{H}_{0}$ ditolak dan $\mathrm{H}_{1}$ diterima. Berarti ada pengaruh antara variabel terikat dengan variabel bebas.

2) Bila $t_{\text {hitung }}<t_{\text {tabel }}$, maka $H_{0}$ diterima dan $H_{1}$ ditolak. Berarti tidak ada pengaruh antara variabel terikat dengan variabel bebas.

d. Dari Tabel 4.12 di atas diketahui bahwa uji nilai t hitung :

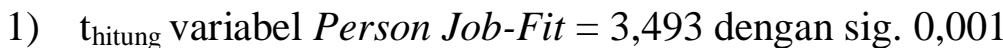

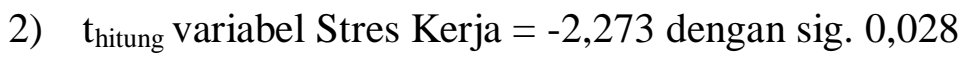

e. Pengujian

1) Variabel Person Job-Fit $\left(\mathrm{X}_{1}\right)$ 


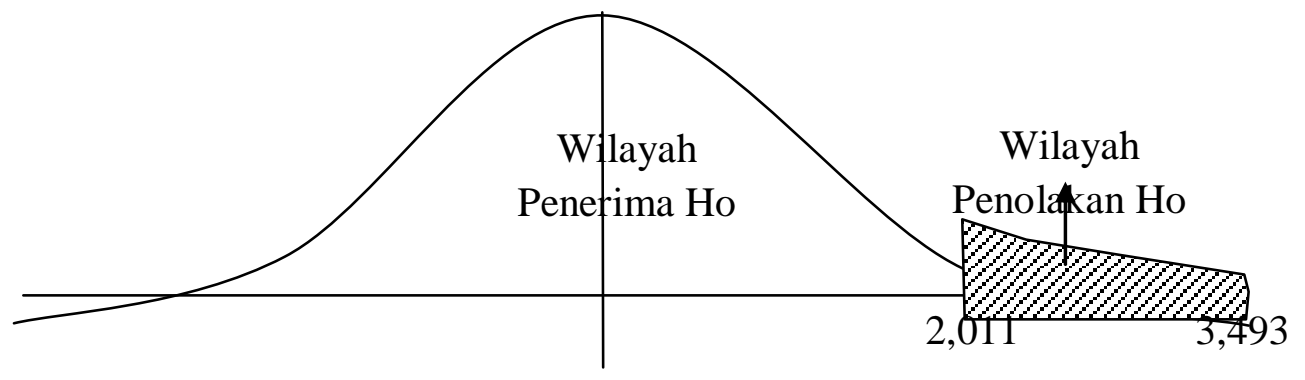

Gambar 4.1 Kurva Uji t VariabelPerson Job-Fit

Berdasarkan hasil nilai $t_{\text {hitung }}$ sebesar 3,493 dan $t_{\text {tabel }}$ sebesar 2,011 maka $\left(t_{\text {hitung }}>\right.$ $\left.\mathrm{t}_{\text {tabel }}\right)$. Kemudian dari tingkat signifikan sebesar 0,001 lebih kecil dari 0,05 (0,001 < 0,05) maka $\mathrm{H}_{0}$ ditolak dan $\mathrm{H}_{1}$ diterima. Hal ini berarti bahwa untuk variabel Person Job-Fitsecara parsial memiliki pengaruh yang signifikan terhadap Kepuasan Kerja.

2) Variabel Stres Kerja $\left(X_{2}\right)$

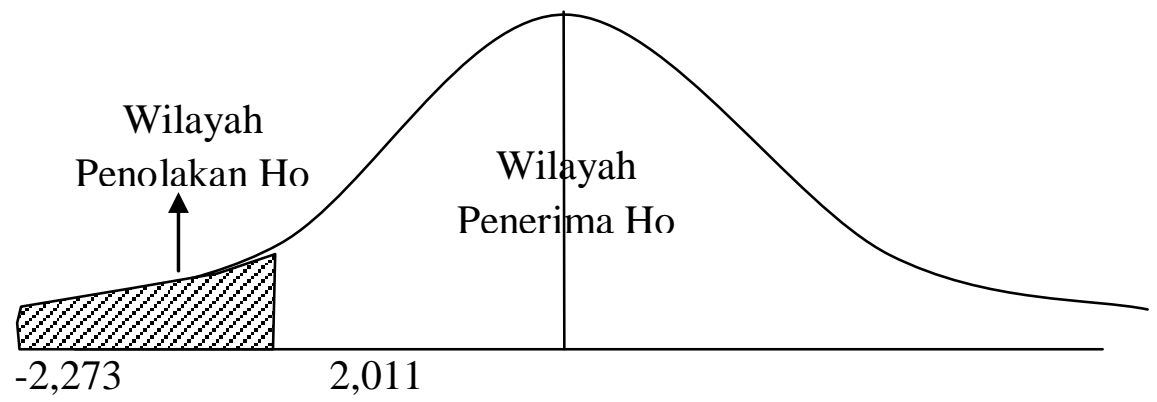

Gambar 4.2 Kurva Uji t Variabel Stres Kerja

Berdasarkan hasil nilai $t_{\text {hitung }}$ sebesar -2,273 dan $t_{\text {tabel }}$ sebesar 2,011 maka $\left(t_{\text {hitung }}<\right.$ $\left.\mathrm{t}_{\text {tabel }}\right)$. Kemudian dari tingkat signifikan sebesar 0,028 lebih kecil dari 0,05 (0,028 < 0,05) maka $\mathrm{H}_{0}$ diterima dan $\mathrm{H}_{1}$ ditolak. Hal ini berarti bahwa untuk variabel Stres Kerja secara parsial terdapat pengaruh negatif yang signifikan terhadap Kepuasan Kerja.

Uji koefisiensi determinasi $\left(\mathrm{R}^{2}\right)$ digunakan untuk mengetahui seberapa jauh kemampuan model dalam menerangkan variasi variabel terikat, berikut hasil uji koefisien determinasi. 
Tabel 4.2 Koefisien Determinasi

\begin{tabular}{|l|r|r|l|r|}
\hline \multicolumn{5}{|c|}{ Model Summary } \\
\hline Model & $\mathrm{R}$ & R Square & Adjusted R Square & $\begin{array}{c}\text { Std. Error of the } \\
\text { Estimate }\end{array}$ \\
\hline 1 & $.703^{\mathrm{a}}$ & .494 & .472 & 6.64167 \\
\hline a. Predictors: (Constant), Stres Kerja, Person Job-Fit \\
\hline \multicolumn{5}{|c|}{ Model Summary } \\
\hline
\end{tabular}

Sumber Data : Hasil Perhitungan SPSS, Lampiran 6

Berdasarkan tabel diatas menunjukkan bahwa besarnya nilai Adjusted $R$ Square aadalah 0,472 hal ini berarti 94,4\% variasi dependen (Kepuasan Kerja) dapat dijelaskan oleh variasi dari kedua variabel independen (Person Job-Fit dan Stres Kerja), sedangkan sisanya 5,6\% dijelaskan oleh sebab-sebab yang lain diluar model.

\section{Pembahasan}

\section{Pengaruh Person Job-Fit Pada Karyawan Outsource Bank BCA KCU Madiun}

Person Job-Fit menurut Rosari (2009:258) adalah ketika kepribadian karyawan dengan pekerjaan sejalan maka kepuasan dari karyawan akan meningkat dengan sendirinya. Artinya seseorang akan lebih memahami makna dari pekerjaannya sehingga dapat kesempatan untuk mengembangkan dirinya di dalam dunia kerja.

Berdasarkan hasil pengujian hipotesis menunjukkan bahwa terdapat pengaruh yang signifikan secara parsial antara Person Job-Fit terhadap Kepuasan Kerja pada Karyawan Outsource Bank BCA KCU Madiun. Jawaban responden menunjukan bahwa skor rata-rata di atas 3 karena responden kebanyakan menjawab setuju dan netral pada item Person Job-Fit. Rasa percaya diri karyawan saat bekerja, cepat saat menyelesaiakn pekerjaan, bisa bekerja secara tim maupun individu, mampu berkomunikasi dengan baik hal ini nantinya akan meningkatkan kepuasan kerja karyawan.

Jawaban responden menunjukan bahwa skor rata-rata di bawah 3 karena responden kebanyakan menjawab tidak setuju atau netral pada item stress kerja. Stress kerja bisa terjadi karena tuntutan pekerjaan yang tinggi, pekerjaan yang menumpuk terlalu banyak dan jarangnya komunikasi juga perbedaan pendapat antar 
karyawan satu dengan karyawan lainnya yang pada akhirnya akan menurunkan kepuasan kerja.

Penelitian ini sesuai dengan penelitian yang dilakukan oleh Ollani Vabiola Bangun, I Wayan Gede Supartha dan Made Subudi (2017) tentang Pengaruh PersonJob Fit Dan Person-Organization Fit Terhadap Komitmen Organisasional Dan Organizational Citizenship Behavior (OCB). Hasil penelitian ini menunjukan bahwa person-job fit berpengaruh positif dan signifikan terhadap komitmen organisasional dan OCB, person-organization fit berpengaruh positif dan signifikan terhadap komitmen organisasional tetapi tidak berpengaruh signifikan terhadap OCB

Namun hal ini berbeda dengan penelitian yang dilakukan oleh Muhammad Arsyad Al Banjari (2017) Pengaruh Person Job Fit dan Budaya Kerja Terhadap Organizational Citizenship Behavior Karyawan Kantor Rektorat Universitas Islam Kalimantan (Uniska). Berdasarkan hasil analisis dan pembahasan, maka dapat dinyatakan bahwa person job fit tidak signifikan dan tidak berpengaruh terhadap Organizational Citizenship Behavior Atau kewargaan prilaku karyawan Kantor Rektorat Universitas Islam Kalimantan (Uniska).

Pengaruh Person Job-Fit Terhadap Kepuasan Kerja di paparkan oleh beberapa faktor seperti faktor pendorong kreatifitas individu, tahapan membangun kreativitas, dan motivasi yang mendorong seseorang untuk menunjukan perilaku tertentu.

\section{Pengaruh Stres Kerja Pada Karyawan Outsource Bank BCA KCU Madiun}

Sondang P. Siagian (2014) mengemukakan bahwa stres kerja merupakan situasi menegangkan yang mempengaruhi emosi dan pola pikir seseorang. Jika stres kerja tidak diatasi dengan bijak maka akan berakibat pada ketidak mampuan seseorang berkomunikasi dengan lingkungannya. Artinya karyawan yang mengalami stres kerja akan dihadapkan gejala buruk yang dapat mempengaruhi prestasi kerjanya. Berdasarkan hasil pengujian hipotesis menunjukkan bahwa terdapat pengaruh yang signifikan negatif secara parsial antara Stres Kerja terhadap Kepuasan Kerja pada Karyawan Outsource Bank BCA KCU Madiun.

Hasil penelitian ini sesuai dengan penelitian terdahulu oleh Yasinta Indah Nastiti (2016) dalam penelitian yang membahas tentang Pengaruh Stres Kerja Terhadap Kinerja Karyawan Pada Perusahaan Batik Brotoseno Sragen menunjukkan bahwa 
hasil variabel stres kerja lingkungan memiliki pengaruh signifikan negatif terhadap kinerja karyawan. Penelitian ini berbanding terbalik dengan penelitian yang dilakukan oleh Niken Widyastuti (2016) dengan judul Pengaruh Stres Kerja Dan Beban Kerja Terhadap Kinerja SKPD Kabupaten Sintang Kalimantan Barat menunjukkan bahwa stres kerja (X1) berpengaruh terhadap kinerja pegawai/SKPD (Y). Variabel beban kerja (X2) berpengaruh terhadap kinerja pegawai (Y).Variabel stres kerja dan beban kerja secara simultan berpengaruh terhadap kinerja SKPD Kabupaten Sintang Kalimantan Barat.

Pengaruh Stres kerja terhadap Kepuasan Kerja dipaparkan oleh beberapa faktor seperti sifat karyawan yang mudah tersinggung yang berpengaruh terhadap mutu pekerjaan karyawan, tidak komunikatifnya karyawan yang mempengaruhi kualitas kerja, kebiasaan karyawan yang banyak melamun saat bekerja, karyawan yang merasa mudah lelah setelah menyelesaikan pekerjaannya, meningkatnya detak jantung dan tekanan darah yang mengganggu konsentrasi karyawan saat bekerja, sulitnya tidur yang berakibat pada efektivitas pekerjaan karyawan, seringnya karyawan yang suka atau sering menunda pekerjaan, dan perilaku sabotase yang terjadi pada sesama karyawan yang dapat menyebabkan stres pada diri seorang karyawan sehingga karyawan tersebut akan merasa terbebani dengan pencapaian target waktu yang telah ditetapkan oleh perusahaan dan bahkan dapat menurunkan kinerja karyawan.

\section{E. SIMPULAN}

1. Bahwa terdapat pengaruh yang signifikan secara parsial antara Person Job-Fit terhadap Kepuasan Kerja pada Karyawan Outsource Bank BCA KCU Madiun. Hal ini terjadi karena adanya kesesuaian antara karakteristik tugas pekerjaan dengan kebutuhan individu untuk melaksanakan tugas tersebut, akan memperkuat keikatan karyawan pada saat bekerja, yaitu karyawan akan lebih komitmen terhadap pekerjaan.

2. Bahwa terdapat pengaruh negativ yang signifikan secara parsial antara Stres Kerja terhadap Kepuasan Kerja pada Karyawan Outsource Bank BCA KCU Madiun. Hal ini terjadi karena banyaknya karyawan yang tidak suka dengan pekerjaan lembur dan tuntutan pekerjaan yang tinggi maka berakibat terhadap kepuasan kerja karyawan. 


\section{DAFTAR PUSTAKA}

A.A. Anwar Prabu Mangkunegara. 2010. Evaluasi Kinerja SDM, Bandung: PT. Refika Aditama.

A.A. Anwar Prabu Mangkunegara. 2013. Manajemen Sumber Daya Manusia Perusahaan, Bandung: Remaja Rosdakarya.

Abdillah, R \& Satiningsih. 2013. Hubungan Antara Tipe Kepribadian Enterprising Pada Teori Person-Job Fit Dengan Kinerja Karyawan Pemasaran UD. Sumber Lestari Sidoarjo. Jurnal Ekonomi dan Bisnis, Vol 1. No 2, hal.10-20.

Anoraga, Pandji \& Pakarti, Piji. 2008. Pengantar Pasar Modal.Cet. 3. Jakarta: Rineka Cipta.

Arikunto, Suharsimi. 2010. Prosedur Penelitian Suatu pendekatan Praktek. Jakarta: Rineka Cipta.

Bohlander, George., and Snell, Scott. 2014. Principles of Human Resource. Management, 15th ed. Mason, $\mathrm{OH}$ : South Western - Cengage Learning.

Cable, D.M. danDeRue D.S. 2002. The Convergent dan Discriminant Validity of Subjective Fit Perceptions, Journal of Applied Psychology, 87(5), 875-884

Ghozali, Imam. 2016. Aplikasi Analisis Multivariete Dengan Program IBM SPSS 23 (Edisi 8). Cetakanke VIII. Semarang : Badan Penerbit Universitas Diponegoro.

Handoko, T. Hani. 2011. Manajemen Personalia dan Sumber Daya Manusia. Yogyakarta: Penerbit BPFE.

Hasibuan, Malayu S.P. 2016. Manajemen Sumber Daya Manusia. Edisi Revisi. Jakarta : Penerbit PT Bumi Aksara.

Hasibuan, Malayu S.P., 2011. Manajemen Sumber Daya Manusia. Jakarta : BumiAksara.

Karissa Sekar Ayu dan Th. Agung M. Harsiwi. 2016. Pengaruh Person-Organization Fit Terhadap Kepuasan Kerja Dengan Dukungan Atasan Langsung Sebagai Pemediasi Pada UD. Kapas Modern Yogyakarta.

Margiati, Lulus. 2011. Stres Kerja : Latar Belakang, Penyebab dan Alternatif Pemecahannya. Jurnal Masyarakat, Kebudayaan dan Politik. Vol. 11 No.3.Hal 78.

Mello, Jeffrey A. 2011. Strategic Human Resource Management ( $3^{\text {rd }}$ edition). United States of America : South-Western Publishing Co.

Muhammad Alfani \& Muhammad Handani. 2017. Kantor Rektorat Uniska.

Vol. No. 2

Mondy \& Noe. 2010. Human Resources Management. Jakarta : Salemba Empat. 
Niken Widyastuti. 2016. Pengaruh Stres Kerja Dan Beban Kerja Terhadap Kinerja SKPD Kabupaten Sintang Kalimantan Barat

Ollani Vabiola Bangun, I Wayan Gede Supartha dan Made Subudi. 2017. Pengaruh Person-Job Fit Dan Person-Organization Fit Terhadap Komitmen Organisasional Dan Organizational Citizenship Behavior (OCB).

Robbins SP, dan Judge. 2008. Perilaku Organisasi, Jakarta:Salemba Empat.

Robbins, Stephen P. dan Coulter, Mary. 2010. Manajemen Edisi Kesepuluh. Jakarta: Penerbit Erlangga

Rosari, Sasmita. 2009. Hubungan antara Budaya Perusahaan terhadap Pengembangan Karir pada Karyawan PT. Bank Mandiri Tbk. Yogyakarta

Sondang Siagian. 2013.Manajemen Sumber Daya Manusia, Bandung: Bumi Aksara.

Sopiah. 2008. Perilaku Organisasi, Yogyakarta: Andi Offset.

Sudarmanto. 2015. Kinerja dan Pengembangan Kompetensi SDM, Edisi Tiga. Yogyakarta : Pustaka Pelajar.

Sugiyono. 2011. Metode Penelitian Kuantitatif, Kualitatif dan R\&D. Bandung: Afabeta

Yasinta Indah Nastiti. 2016. Pengaruh Stres Kerja Terhadap Kinerja Karyawan Pada Perusahaan Batik Brotoseno Sragen. 